\title{
Infant feeding practices, childhood growth and obesity in adult life
}

\author{
Práticas alimentares na infância, crescimento \\ infantil e obesidade na vida adulta
}

Bárbara Hatzlhoffer Lourenço', Marly Augusto Cardoso'

${ }^{1}$ Departamento de Nutrição, Faculdade de Saúde Pública, Universidade de São Paulo (FSP/USP), São Paulo, SP, Brasi
Correspondence to: Marly Augusto Cardoso Departamento de Nutrição, Faculdade de Saúde Pública da Universidade de São Paulo Av. Doutor Arnaldo, 715, 2o anda 01246-904 - São Paulo, SP, Brasil marlyac@usp.br

\begin{abstract}
Child health is widely affected by nutritional status, and there is growing interest surrounding the possibility that child nutritional status and infant feeding practices may be linked to obesity in adulthood, increasing risks of metabolic complications. Prospective studies enable appropriate investigation and evaluation of the determinants of childhood development. The present paper therefore aimed to provide a review of the main evidence to date from longitudinal studies concerning the associations of infant feeding practices, patterns of childhood growth and nutritional status exhibited in adult life. Arq Bras Endocrinol Metab. 2009;53(5):528-39.
\end{abstract}

Keywords

Infant feeding practices; diet; growth; overweight; obesity

\section{RESUMO}

A saúde infantil é amplamente afetada pelo estado nutricional. Há um interesse crescente acerca da possibilidade do estado nutricional apresentado pela criança e das práticas alimentares na primeira infância estarem relacionados à obesidade em indivíduos adultos, aumentando os riscos para complicações metabólicas. Sabe-se que estudos prospectivos possibilitam a investigação e a avaliação apropriadas de determinantes do desenvolvimento infantil. Consequentemente, o presente artigo objetivou revisar as principais evidências disponíveis a partir de estudos longitudinais sobre associações entre práticas alimentares na primeira infância, padrões de crescimento infantil e estado nutricional verificados durante a vida adulta. Arq Bras Endocrinol Metab. 2009;53(5):528-39.

Descritores

Práticas alimentares na infância; dieta; crescimento; sobrepeso; obesidade

\section{INTRODUCTION}

hild health is widely affected by nutritional status. Malnutrition encompasses different forms of undernutrition as well as obesity, and, when detected in early life, commonly leads to permanent damage which, in turn, can also affect future generations (1). There is growing interest surrounding the possibility that child nutritional status and infant feeding practices may be linked to abdominal obesity in adult life, increasing risks of metabolic complications.

Along these lines, a number of cross-sectional investigations have been conducted among developing countries. In Brazil, Hoffman and cols. $(2,3)$ performed a resident study to examine metabolic and dietetic variables in a group of shantytown stunted and normal height children. They concluded that the condition of childhood stunting was associated with impaired fat oxidation and with opportunistic overeating, revealing that stunted children may be at increased risk of excess weight gain over time under favorable environmental conditions. In another study among a rural low-income Mexican population, a community-based survey indicated that stunting coexisted with overweight and obesity in pre-school children aged 24 to 72 months, especially in conjunction with lower socioeconomic status (4).

Likewise, investigating the relationship between infant feeding practices and overweight, Jingxiong and cols. (5) evaluated children aged 12 to 35 months in a sub-sample from randomly selected communities drawn from an urban area of Beijing. Even in this young age 
group, they were able to demonstrate that, compared to their normal weight peers, a lower percentage of overweight children were breastfed for, at least, four months, while these children also received significantly more infant formulas or semi-solid food during their first four months of life.

Bearing in mind that prospective studies enable appropriate investigation and evaluation of the determinants of childhood development, the present paper aimed to provide a review of the main evidence to date from longitudinal studies concerning the associations of infant feeding practices, patterns of childhood growth and nutritional status exhibited in adult life.

\section{METHODS}

Relevant articles published between 1980 and 2009 were identified by searching the MedLine database (National Library of Medicine, Bethesda, MD, USA). Search terms included birth cohort or longitudinal studies, infant feeding practices, childhood growth, adolescence, adulthood, obesity and weight gain. Studies were examined through their abstracts and included in the review if they prospectively examined the association of feeding practices assessed in early life (e.g. breastfeeding, use of milk thickeners, complementary diet, from birth to three years) or dietary factors throughout childhood (e.g. energy and/or nutrient intake, dietary patterns, household food insecurity status) with parameters of childhood growth and/or obesity in adult life. Articles were classified according to sample size, length of follow-up, exposure variables analyzed, main outcomes and key findings.

\section{OVERVIEW OF STUDIES AND MAIN FINDINGS}

Applying the inclusion criteria, 22 relevant original articles were included in this review following the literature search. The main findings of each of these articles are depicted in tables 1 and 2, which also include exposures and outcomes evaluated. In table 1 , studies that assessed specific infant feeding parameters as exposures of interest - such as breastfeeding duration, bottle-feeding, introduction of complementary or solid food and use of formulas and milk thickeners - are listed. Additionally, table 2 summarizes studies that appraised other dietary factors as exposures of interest, mainly related to food, nutrient and energy intake.
Studies defined different aspects of infant feeding practices. Duration of total breastfeeding was established in weeks or months before full weaning, and the dichotomous variable "ever breastfed" was also commonly applied. Exclusive breastfeeding, defined as no supplementing with formula, evaporated milk or other solid or fluid foods beyond breast milk, was extremely short. Furthermore, some investigations were unable to determine the exact beginning of supplemental feeding among their subjects. As a result, predominant breastfeeding (breast milk in addition to water and/ or teas, only) and partial breastfeeding (breast milk used in combination with other milk supplements and foods) were most frequently assessed. Age at formula and complementary food or solid food introduction in weeks or months was also estimated in several studies. Food, energy and nutrient intakes had been analyzed using different dietary assessment methods, such as multiple-pass 24-hour recalls, and weighted or unweighted dietary records, ranging from one to four-day records. More specific features and designations of each study will be described when discussing their results.

Overweight and obesity status during childhood were evaluated in some studies - included in this review. Nevertheless, classification criteria varied among authors. The assessments of childhood overweight and obesity were based on:

- the National Center for Health Statistics (NCHS) and World Health Organization (WHO) 1977 growth charts;

- the NCHS and Center for Disease Control and Prevention (CDC) 2000 growth charts;

- the International Obesity Task Force (IOTF) body mass index (BMI) cut-off points based on age-specific values (from 2 to 18 years) that project to the adult cut-offs of $25 \mathrm{~kg} / \mathrm{m}^{2}$ for overweight and $30 \mathrm{~kg} / \mathrm{m}^{2}$ for obesity, using data from six different reference populations (6).

- A brief description of the criteria adopted in each study will be provided.

Overall, the analyses of these articles included 105 to 177,304 subjects, and the period of follow-up varied from 1 to 62 years. These 22 publications draw conclusions from 19 separate longitudinal investigations conducted in different countries, namely, Australia, Brazil, Denmark, Finland, Sweden, the United Kingdom and the United States, as shown in tables 1 and 2. According to the distribution found in the tables of this review, studies are discussed under the following sections. 
Table 1. Longitudinal studies on the associations of infant feeding practices, childhood growth and nutritional status in adult life

\begin{tabular}{|c|c|c|c|c|c|c|}
\hline Study & City, country & $\begin{array}{c}\text { Sample's } \\
\text { characteristics }\end{array}$ & $\begin{array}{l}\text { Period of } \\
\text { follow-up }\end{array}$ & $\begin{array}{l}\text { Main dietary } \\
\text { exposures }\end{array}$ & Outcomes & Findings \\
\hline $\begin{array}{l}\text { Wilson and } \\
\text { cols. (14) }\end{array}$ & $\begin{array}{l}\text { Dundee, United } \\
\text { Kingdom }\end{array}$ & $\begin{array}{c}\mathrm{n}=545 \\
45.9 \% \text { male } \\
\text { Dundee Infant } \\
\text { Feeding Study }\end{array}$ & 7 years & $\begin{array}{l}\text { Duration of breast and } \\
\text { formula feeding, age of } \\
\text { introduction of formula } \\
\text { and solid foods }\end{array}$ & $\begin{array}{l}\text { Growth and BC } \\
\text { (skinfold thickness and } \\
\text { electrical impedance) } \\
\text { in childhood }\end{array}$ & $\begin{array}{l}\text { Inverse association between age of } \\
\text { introduction of solid foods and weight }(p< \\
0.025) \text { and percentage of body fat }(p<0.01) \\
\text { at } 7 \text { years. Adjusted for sex, birth weight, } \\
\text { weight at first solid feed }\end{array}$ \\
\hline
\end{tabular}

Tulldahl and Sweden $\quad \mathrm{n}=781 \quad \mathrm{BF}$ years duration (data High BMI and BC (dual Inverse association between exclusive BF $<$

cols. (17)

$50.7 \%$ male

194 individuals with

dual energy X-ray

data

$\begin{array}{lcc}\begin{array}{l}\text { Ong and } \\ \text { cols. (13) }\end{array} & \begin{array}{c}\text { Avon, United } \\ \text { Kingdom }\end{array} & \begin{array}{c}\mathrm{n}=1,335 \\ \text { ALSPAC Children in } \\ \text { Focus Cohort }\end{array} \\ & & \\ \begin{array}{l}\text { Victora and } \\ \text { cols. (18) }\end{array} & \text { Pelotas, Brazil } & \mathrm{n}=2,250 \\ & & \text { Only male } \\ & & \text { Pelotas Birth Cohort } \\ & & \text { Population based }\end{array}$

5 years $\begin{array}{ccc}\text { assessed at } 15 \text { to } 16 & \text { energy } X \text {-ray) at } 17 \text { to } & 2 \text { months and } B M I\left(\chi^{2} \text { test; } p=0.038\right) \text {. No } \\ \text { years, retrospectively) } & 18 \text { years } & \text { significant association between } B F \text { duration }\end{array}$ and BC. No adjustment for confounders

Breast or bottle feeding

Childhood growth

Breastfed children showed a slower weight (weight and length or and length gain when compared to height) from birth to 5 bottle-fed children, despite having similar years birth weight. Weight was significantly different at 31 months ( $p=0.02)$, excluding maternal smokers.

18 years

Total and predominant BF duration

Adiposity at 18 years (BMI, OW and OB, lean and fat mass by electrical impedance) predominant BF and overweight status, mean $\mathrm{BMI}$, lean and fat mass

Population based

\begin{tabular}{|c|c|c|c|c|c|c|}
\hline $\begin{array}{l}\text { Bogen and } \\
\text { cols. (11) }\end{array}$ & Ohio, USA & $\begin{array}{c}n=73,458 \\
72.0 \% \text { white } \\
\text { Low-income } \\
\text { children } \\
\text { Retrospective cohort } \\
\text { study }\end{array}$ & 4 years & $\begin{array}{l}\text { BF duration with and } \\
\text { without concurrent } \\
\text { formula usage }\end{array}$ & $\begin{array}{l}\text { Prevalence of obesity } \\
\text { at } 4 \text { years }\end{array}$ & $\begin{array}{l}\text { For white children whose mothers did not } \\
\text { smoke during pregnancy, BF showed a } \\
\text { protective effect against obesity at } 4 \text { years: } \\
\mathrm{OR}=0.55(95 \% \mathrm{Cl}=0.42-0.71) \text { for } \mathrm{BF}>26 \\
\text { weeks without early formula introduction. } \\
\text { Adjusted for maternal age, education, parity, } \\
\text { marital status, pregnancy conditions, } \\
\text { delivery method, child sex, birth weight, } \\
\text { birth year, birth order }\end{array}$ \\
\hline $\begin{array}{l}\text { Grummer- } \\
\text { Strawn and } \\
\text { cols. (12) }\end{array}$ & USA & $\begin{array}{c}\mathrm{n}=17,7304 \\
52.1 \% \text { white } \\
\text { non-Hispanic } \\
\text { Low-income } \\
\text { children enrolled in } \\
\text { public health } \\
\text { programs } \\
\text { 12,587 children } \\
\text { with mothers' data } \\
\text { available }\end{array}$ & 4 years & BF duration & $\mathrm{OW}$ at 4 years & $\begin{array}{l}\text { Dose-response, protective relationship of } \\
\mathrm{BF} \text { duration with the risk of OW among } \\
\text { non-Hispanic whites: } \mathrm{BF} \text { for } 6 \text { to } 12 \text { months, } \\
\mathrm{OR}=0.70(95 \% \mathrm{Cl}=0.50-0.99) ; \mathrm{BF}>12 \\
\text { months, } \mathrm{OR}=0.49(95 \% \mathrm{Cl}=0.25-0.95) \text {. } \\
\text { Adjusted for child's gender, birth weight, } \\
\text { race/ethnicity, and mother's age, education, } \\
\text { pre-pregnancy BMI, weight gain during } \\
\text { pregnancy, postpartum smoking }\end{array}$ \\
\hline $\begin{array}{l}\text { Baker and } \\
\text { cols. (7) }\end{array}$ & Denmark & $\begin{array}{c}n=3,768 \\
50.5 \% \text { male } \\
\text { Denmark National } \\
\text { Birth Cohort }\end{array}$ & 1 year & $\begin{array}{l}\text { Duration of any BF and } \\
\text { CF introduction }\end{array}$ & $\begin{array}{l}\text { Infant weight gain from } \\
\text { birth to } 1 \text { year }\end{array}$ & $\begin{array}{l}\text { Positive association between weight gain } \\
\text { from birth to } 1 \text { year and decreasing duration } \\
\text { of any } \mathrm{BF} \text { and earlier introduction of } \mathrm{CF} \text {, } \\
\text { especially at the lowest quartile of any } \mathrm{BF} \text { ( } \mathrm{p} \\
<0.0001 \text { ). At longer durations of any } \mathrm{BF} \text {, } \\
\text { timing of } \mathrm{CF} \text { introduction was not } \\
\text { associated with weight gain. Adjusted for } \\
\text { primiparity, gestational weight gain, } \\
\text { duration of gestation, smoking during } \\
\text { pregnancy, infant sex, infant birth weight, } \\
\text { infant length at } 1 \text { year, infant age at time of } \\
\text { the } 1 \text {-year anthropometric measurements }\end{array}$ \\
\hline
\end{tabular}




\begin{tabular}{|c|c|c|c|c|c|c|}
\hline Study & City, country & $\begin{array}{c}\text { Sample's } \\
\text { characteristics }\end{array}$ & $\begin{array}{l}\text { Period of } \\
\text { follow-up }\end{array}$ & $\begin{array}{l}\text { Main dietary } \\
\text { exposures }\end{array}$ & Outcomes & Findings \\
\hline $\begin{array}{l}\text { Agras and } \\
\text { cols. (16) }\end{array}$ & $\begin{array}{c}\text { San Francisco, } \\
\text { USA }\end{array}$ & $\begin{array}{c}n=150 \\
49.3 \% \text { male }\end{array}$ & 9.5 years & $\begin{array}{l}\text { Infant feeding practices } \\
\text { and behaviors, } \\
\text { childhood eating } \\
\text { behaviors, } 24 \text { hours } \\
\text { child caloric intake }\end{array}$ & $\begin{array}{l}\text { Development of } \\
\text { childhood OW }\end{array}$ & $\begin{array}{l}\text { Positive association between } 0 \text { at } 9.5 \\
\text { years and tantrums over food during } \\
\text { childhood }(R=0.26) \text {, which in turn correlate } \\
\text { significantly with anger/frustration ( } R= \\
0.25 \text { ) and soothability }(R=-0.24)\end{array}$ \\
\hline $\begin{array}{l}\text { Stettler and } \\
\text { cols. (15) }\end{array}$ & USA & $\begin{array}{c}\mathrm{n}=5,479 \\
\text { (individuals with } \\
\text { information on } \\
\text { initial infant feeding } \\
\text { method) } \\
\text { National } \\
\text { Collaborative } \\
\text { Perinatal Project } \\
\text { (CPP) }\end{array}$ & 7 years & BF initiation* & $\mathrm{OW}$ at 7 years & $\begin{array}{l}\text { No significant association between } \mathrm{BF} \\
\text { initiation and overweight at } 7 \text { years ( } \mathrm{OR}= \\
1.28 ; 95 \% \mathrm{Cl}=087-1.88) \text {. No interaction } \\
\text { detected for } \mathrm{BF} \text { initiation in association of } \\
\text { early rate of weight gain and overweight at } 7 \\
\text { years }\end{array}$ \\
\hline $\begin{array}{l}\text { Nelson and } \\
\text { cols. (20) }\end{array}$ & USA & $\begin{array}{l}\mathrm{n}=11,998 \\
850 \text { sibling pairs } \\
\text { were assessed to } \\
\text { account for } \\
\text { unmeasured genetic } \\
\text { and environmental } \\
\text { factors } \\
\text { National } \\
\text { Longitudinal Study } \\
\text { of Adolescent } \\
\text { Health }\end{array}$ & 2 years & Duration of any BF & Adolescent OW & $\begin{array}{l}\text { Inverse association between duration of any } \\
\mathrm{BF} \text { and } \mathrm{OW} \text { among girls in the full cohort: } \\
\mathrm{BF} \geq 9 \text { months, } \mathrm{OR}=0.78 \text { ( } 95 \% \mathrm{Cl}= \\
0.64-0.96) \text {. No significant associations } \\
\text { found in sibling pairs analyses. Adjustment } \\
\text { for confounders in full cohort (ethnicity, } \\
\text { family income) and in sibling pairs (age, } \\
\text { sex, birth order, low birth weight status) }\end{array}$ \\
\hline $\begin{array}{l}\text { Santos and } \\
\text { cols. (9) }\end{array}$ & Pelotas, Brazil & $\begin{array}{l}\qquad n=596 \\
\text { Pelotas Birth Cohort }\end{array}$ & 1 to 4 years & $\begin{array}{c}\text { Use of milk thickeners } \\
\text { between } 3 \text { and } 6 \\
\text { months }\end{array}$ & $\begin{array}{l}\text { Weight, length/height, } \\
\text { and anthropometric } \\
\text { indices (WA, L/HA, } \\
\text { WL/H) at } 1 \text { and } 4 \text { years }\end{array}$ & $\begin{array}{l}\text { Positive association between use of milk } \\
\text { thickeners and weight }(\beta=0.160 ; 95 \% \mathrm{Cl}= \\
0.009-0.312) \text {, length }(\beta=0.540 ; 95 \% \mathrm{Cl}= \\
0.141-0.939) \text {, WA ( } \beta=0.155 ; 95 \% \mathrm{Cl}= \\
0.013-0.296) \text { and } \mathrm{LA}(\beta=0.188 ; 95 \% \mathrm{Cl}= \\
0.051-0.325) \text { at } 1 \text { year. No significant } \\
\text { associations between use of milk thickeners } \\
\text { and anthropometric indices at } 4 \text { years. } \\
\text { Adjusted for maternal skin color, age, } \\
\text { education, marital status, parity, multiple } \\
\text { birth, birth weight, gestational age, sex, } \\
\text { cough, hospitalization, anthropometric } \\
\text { parameters at } 3 \text { months }\end{array}$ \\
\hline $\begin{array}{l}\text { Araújo and } \\
\text { cols. (10) }\end{array}$ & Pelotas, Brazil & $\begin{array}{c}\qquad \mathrm{n}=1,273 \\
49.2 \% \text { male } \\
76.9 \% \text { white } \\
\text { Pelotas Birth Cohort } \\
\text { Population based }\end{array}$ & 4 years & $\begin{array}{l}\text { BF duration (total and } \\
\text { predominant) and ever } \\
\text { breastfed }\end{array}$ & $\begin{array}{c}\text { Prevalence of } \mathrm{OW} \text { and } \\
\text { WH at } 4 \text { years }\end{array}$ & $\begin{array}{l}\text { No linear trends and no significant } \\
\text { associations between duration of total and } \\
\text { predominant } \mathrm{BF} \text { and outcomes }(\mathrm{p}>0.05) \text {. } \\
\mathrm{OR}=1.83(95 \% \mathrm{Cl}=0.53-6.28) \text { for } \mathrm{OW} \text { if } \\
\text { ever breastfed. Coefficient }=0.24(95 \% \mathrm{Cl}= \\
-0.09-0.57) \text { for mean WH if ever breastfed. } \\
\text { Adjusted for infant sex, skin color and birth } \\
\text { weight, assets index, maternal schooling, } \\
\text { smoking during pregnancy, pregestional } \\
\mathrm{BMI} \text { and weight gain during pregnancy }\end{array}$ \\
\hline $\begin{array}{l}\text { Michels and } \\
\text { cols. (19) }\end{array}$ & USA & $\begin{array}{c}\mathrm{n}=35,526 \\
\text { Only female } \\
96 \% \text { Caucasian } \\
\text { white } \\
\text { Nurses' Health } \\
\text { Study II } \\
\text { (1989-2001) } \\
\text { Nurses' Mothers' } \\
\text { Cohort Study } \\
\text { (maternal report of } \\
\text { infant feeding } \\
\text { practices, familial, } \\
\text { maternal and birth } \\
\text { variables) }\end{array}$ & 12 years & $\begin{array}{l}\text { BF initiation and } \\
\text { duration }\end{array}$ & $\begin{array}{l}\mathrm{OW} \text { and } \mathrm{OB} \text { at } 18 \text { years } \\
\text { and in adulthood } \\
\text { (mean age of breastfed } \\
\text { nurses = } 40.5 \text { years; } \\
\text { not breastfed nurses = } \\
39.3 \text { years) }\end{array}$ & $\begin{array}{l}\text { No significant association between BF } \\
\text { initiation or duration and OW and OB at } 18 \\
\text { years and in adulthood. Adjusted for age of } \\
\text { nurse, year of birth of the nurse, maternal } \\
\text { pre-pregnancy weight and weight gain } \\
\text { during pregnancy, birth weight and } \\
\text { gestational age of the nurse, mother's and } \\
\text { father's education and occupation, home } \\
\text { ownership of parents at time of nurse } \\
\text { daughter's birth, age of nurse at menarche, } \\
\text { parity of nurse, nurse's age at first birth, } \\
\text { nurse's physical activity, daily energy intake }\end{array}$ \\
\hline
\end{tabular}


Table 1. Longitudinal studies on the associations of infant feeding practices, childhood growth and nutritional status in adult life (cont.)

\begin{tabular}{|c|c|c|c|c|c|c|}
\hline Study & City, country & $\begin{array}{c}\text { Sample's } \\
\text { characteristics }\end{array}$ & $\begin{array}{l}\text { Period of } \\
\text { follow-up }\end{array}$ & $\begin{array}{l}\text { Main dietary } \\
\text { exposures }\end{array}$ & Outcomes & Findings \\
\hline $\begin{array}{l}\text { Griffiths and } \\
\text { cols. (8) }\end{array}$ & $\begin{array}{l}\text { England, } \\
\text { Wales, } \\
\text { Scotland and } \\
\text { Northern } \\
\text { Ireland, United } \\
\text { Kingdom }\end{array}$ & $\begin{array}{c}n=10,533 \\
49.9 \% \text { male } \\
\text { UK Millennium } \\
\text { Cohort Study - } \\
\text { MCS } \\
\text { Nationally } \\
\text { representative }\end{array}$ & 3 years & $\begin{array}{l}\text { BF initiation and } \\
\text { duration, age of } \\
\text { introduction of solid } \\
\text { foods }\end{array}$ & $\begin{array}{c}\text { Conditional weight } \\
\text { gain z-score from birth } \\
\text { to } 3 \text { years (adjusted for } \\
\text { birth weight) }\end{array}$ & $\begin{array}{l}\text { Conditional weight gain was significantly } \\
\text { higher among infants given no breast milk ( } \mathrm{R} \\
=0.06 ; 95 \% \mathrm{Cl}=0.02-0.09 \text { ). Negative } \\
\text { association between conditional weight gain } \\
\text { and BF duration ( } \mathrm{R}=0.05 ; 95 \% \mathrm{Cl}= \\
0.01-0.09 \text {; adjusted for age of introduction of } \\
\text { solid food). Overall adjustment (3-year height } \\
\text { z-score, maternal social class, pre-pregnancy } \\
\text { BMI, parity, smoking during pregnancy) }\end{array}$ \\
\hline $\begin{array}{l}\text { 0'Tierney } \\
\text { and cols. } \\
\text { (21) }\end{array}$ & $\begin{array}{l}\text { Helsinki, } \\
\text { Finland }\end{array}$ & $\begin{array}{l}\mathrm{n}=1,823 \\
\text { Breastfed } \\
\text { individuals } \\
\text { belonging to } \\
\text { sibships } \\
\text { Helsinki Birth } \\
\text { Cohort }\end{array}$ & 62 years & BF duration & $\begin{array}{l}\text { Later BMI and } \\
\text { adiposity (percentage } \\
\text { of body fat measured } \\
\text { by electrical } \\
\text { impedance) }\end{array}$ & $\begin{array}{l}\text { Negative association between BF duration and } \\
\text { BMl at } 1 \text { year ( } p<0.05 \text { for linear trend), which } \\
\text { disappeared at } 7 \text { years. U-shaped association } \\
\text { between BF duration and BMI ( } p=0.08 \text { for } \\
\text { quadratic trend) and percentage of body fat ( } p \\
=0.03 \text { for quadratic trend) in later life. } \\
\text { Adjusted for sex, year of birth, size of sibship }\end{array}$ \\
\hline
\end{tabular}

${ }^{*}$ Assumed in Stettler and cols. (2002) study as a potential confounder in the relationship between early rate of weight gain and overweight at 7 years.

BF: breastfeeding; BMl: body mass index; BC: body composition; OW: overweight; OB: obesity status; OR: odds ratio; 95\%Cl: 95\% confidence interval; R: regression coefficient; CF: complementary food; weight for age, length/ height for age, weight for length/height z scores: WA, L/HA, WL/H, respectively.

Table 2. Longitudinal studies on the associations of dietary factors and body composition throughout childhood and adult life

\begin{tabular}{|c|c|c|c|c|c|c|}
\hline Study & City, country & $\begin{array}{c}\text { Sample's } \\
\text { characteristics }\end{array}$ & $\begin{array}{l}\text { Period of } \\
\text { follow-up }\end{array}$ & $\begin{array}{l}\text { Main dietary } \\
\text { exposures }\end{array}$ & Outcomes & Findings \\
\hline $\begin{array}{l}\text { Magarey } \\
\text { and cols. } \\
(27)\end{array}$ & $\begin{array}{l}\text { Adelaide, } \\
\text { Australia }\end{array}$ & $\begin{array}{c}\mathrm{n}=143-243 \\
\text { between ages } 2 \text { and } \\
15 \text { years } \\
51.1-57.9 \% \text { male } \\
\text { between ages } 2 \text { and } \\
15 \text { years } \\
\text { Adelaide Nutrition } \\
\text { Study }\end{array}$ & 13 years & $\begin{array}{c}\text { Energy-adjusted } \\
\text { macronutrient intake at } \\
2,4,6,8,11,13 \text { and } \\
15 \text { years (assessed } \\
\text { through } 3 \text { to } 4 \text { days } \\
\text { weighted dietary } \\
\text { records) }\end{array}$ & $\begin{array}{c}\text { Body fatness at } 2,4,6 \\
8,11,13 \text { and } 15 \text { years } \\
\text { (BMI, TC and SS) }\end{array}$ & $\begin{array}{l}\text { Positive association between fat intake and } \\
\text { SS ( } \beta=0.008 ; p=0.003) \text { and negative } \\
\text { association ( } \beta=-0.003 ; p=0.006 \text { ) between } \\
\text { carbohydrate intake and SS across } 2 \text { to } 15 \\
\text { years according to generalized estimating } \\
\text { equations. In multiple regression analyses, } \\
\text { macronutrient intake was not a good } \\
\text { predictor for adiposity in successive ages. } \\
\text { Adjusted for gender parental adiposity, total } \\
\text { energy intake, level of fatness at the begging } \\
\text { of age interval) }\end{array}$ \\
\hline $\begin{array}{l}\text { Hoppe and } \\
\text { cols. (26) }\end{array}$ & $\begin{array}{l}\text { Copenhagen, } \\
\text { Denmark }\end{array}$ & $\begin{array}{c}n=105 \\
48.6 \% \text { male } \\
\text { Copenhagen Cohort } \\
\text { Study on Infant } \\
\text { Nutrition and } \\
\text { Growth }\end{array}$ & 10 years & $\begin{array}{l}\text { Protein intake in } \\
\text { infancy ( } 9 \text { months) }\end{array}$ & $\begin{array}{c}\text { Body size and } \\
\text { composition in late } \\
\text { childhood (10 years) }\end{array}$ & $\begin{array}{l}\text { No significant association between fatness in } \\
\text { late childhood and protein intake at } 9 \text { months. } \\
\text { Adjusted for sex, energy from protein was a } \\
\text { predictor of weight }(\beta=0.44 ; 95 \% \mathrm{Cl}= \\
0.12-0.76) \text { and height ( } \beta=0.51 ; 95 \% \mathrm{Cl}= \\
0.13-0.90) \text { at } 10 \text { years. Associations were } \\
\text { attenuated and/or disappeared following } \\
\text { inclusion of parental size and body size at } 9 \\
\text { months in regression models }\end{array}$ \\
\hline $\begin{array}{l}\text { Laitinen } \\
\text { and cols. } \\
\text { (28) }\end{array}$ & $\begin{array}{l}\text { Lapland and } \\
\text { Oulu, Finland }\end{array}$ & $\begin{array}{c}\quad n=5,771 \\
49.2 \% \text { male } \\
\text { Northern Finland } \\
1966 \text { Birth Cohort } \\
\text { Study }\end{array}$ & 31 years & $\begin{array}{l}\text { AC at } 14 \text { and } 31 \text { years, } \\
\text { healthy or unhealthy } \\
\text { diet (depend on } \\
\text { frequency of intake of } \\
\text { foods rich in fiber and } \\
\text { consumption of } \\
\text { sausages) at } 31 \text { years }\end{array}$ & $\mathrm{A} 0$ at 31 years & $\begin{array}{l}\text { Positive association between } \mathrm{AO} \text { in men and } \\
\text { high } \mathrm{AC} \text { at } 31 \text { years }(\mathrm{OR}=1.82 ; 95 \% \mathrm{Cl}= \\
1.17-2.85) \text { and unhealthy diet }(\mathrm{OR}=1.53 \text {; } \\
95 \% \mathrm{Cl}=1.03-2.27) \text {, considering } \mathrm{BMI} \text { at } 31 \\
\text { years in regression model. Positive } \\
\text { association between } \mathrm{AO} \text { in women and } \\
\text { regular } \mathrm{AC} \text { at } 14 \text { years ( } \mathrm{OR}=2.63 ; 95 \% \mathrm{Cl}= \\
1.44-4.80) \text {, but it disappeared when } \mathrm{BMI} \text { at } \\
31 \text { years was included in model. Among } \\
\text { women, } \mathrm{AC} \text { at } 31 \text { years showed a } \\
\text { dose-response, protective relationship with } \\
\mathrm{A} 0 \text { (for highest } \mathrm{AC} \text { at } 31 \text { years, } \mathrm{OR}=0.54 ; \\
95 \% \mathrm{Cl}=0.34-0.85) \text {, considering } \mathrm{BMI} \text { at } 31 \\
\text { years in regression model. Adjusted for } \\
\text { maternal age and } \mathrm{BMI} \text { before pregnancy, and } \\
\text { parity and use of hormonal contraception at } \\
31 \text { years among women }\end{array}$ \\
\hline
\end{tabular}




\begin{tabular}{|c|c|c|c|c|c|c|}
\hline Study & City, country & $\begin{array}{c}\text { Sample's } \\
\text { characteristics }\end{array}$ & $\begin{array}{l}\text { Period of } \\
\text { follow-up }\end{array}$ & $\begin{array}{l}\text { Main dietary } \\
\text { exposures }\end{array}$ & Outcomes & Findings \\
\hline $\begin{array}{l}\text { Garnett and } \\
\text { cols. (25) }\end{array}$ & $\begin{array}{l}\text { Sydney, } \\
\text { Australia }\end{array}$ & $\begin{array}{c}n=342 \\
280 \text { individuals } \\
\text { completed dietary } \\
\text { assessment } \\
\text { Longitudinal } \\
\text { Nepean Study }\end{array}$ & 5.4 years & $\begin{array}{l}\text { Nutrient intake at } 7 \text { to } 8 \\
\text { years (assessed } \\
\text { through 3-day food } \\
\text { record) }\end{array}$ & $\begin{array}{l}\text { Total adiposity (BMI) } \\
\text { and central adiposity } \\
\text { (waist circumference) } \\
\text { at } 12 \text { to } 13 \text { years }\end{array}$ & $\begin{array}{l}\text { No significant association between } \mathrm{OW} \text { and } \\
\mathrm{OB} \text { at } 12 \text { to } 13 \text { years (according to BMI or } \\
\text { waist circumference) and macronutrient } \\
\text { intake at } 7 \text { to } 8 \text { years. No adjustment for } \\
\text { confounders }\end{array}$ \\
\hline $\begin{array}{l}\text { Rose and } \\
\text { Bodor (23) }\end{array}$ & USA & $\begin{array}{c}n=16,889 \\
51.4 \% \text { male } \\
58.8 \% \text { white } \\
12,890 \text { individuals } \\
\text { with data about } \\
\text { weight gain } \\
\text { ECLS-K - Early } \\
\text { Childhood } \\
\text { Longitudinal } \\
\text { Study-Kindergarten } \\
\text { Cohort } \\
\text { Nationally } \\
\text { representative }\end{array}$ & 2 years & $\begin{array}{l}\text { Household food } \\
\text { insecurity at } 6 \text { years }\end{array}$ & $\begin{array}{l}\text { Child } 0 W \text { at } 6 \text { years } \\
\text { and } 2 \text { years later }\end{array}$ & $\begin{array}{l}\text { Protective relationship between food } \\
\text { insecurity and } \mathrm{OW} \text { at } 6 \text { years }(\mathrm{OR}=0.80 \text {; } \\
95 \% \mathrm{Cl}=0.66-0.98) \text {. Considering child } \mathrm{OW} \\
2 \text { years later, food insecurity was also } \\
\text { inversely associated with } \mathrm{OW}(\mathrm{OR}=0.73 \text {; } \\
95 \% \mathrm{Cl}=0.57-0.93) \text {. Adjusted for gender, } \\
\text { age, race/ethnicity, birth weight, maternal } \\
\text { schooling, poverty index ratio, country } \\
\text { region, urbanization, physical activity, family } \\
\text { meal patterns }\end{array}$ \\
\hline $\begin{array}{l}\text { Ong and } \\
\text { cols. (24) }\end{array}$ & $\begin{array}{l}\text { Avon, United } \\
\text { Kingdom }\end{array}$ & $\begin{array}{l}\quad n=881 \\
\text { ALSPAC Children in } \\
\text { Focus Cohort }\end{array}$ & 5 years & $\begin{array}{l}\text { Total dietary energy } \\
\text { intake from a 1-day } \\
\text { unweighted dietary } \\
\text { record at } 4 \text { months in } \\
\text { breastfed and } \\
\text { formula- or mixed-fed } \\
\text { children }\end{array}$ & $\begin{array}{l}\text { Weight gain from birth } \\
\text { to } 5 \text { years }\end{array}$ & $\begin{array}{l}\text { Positive association between energy intake at } \\
4 \text { months and rates of rapid weight gain from } \\
0 \text { to } 2 \text { years ( } p<0.0001 \text { for trend). Higher } \\
\text { energy intake at } 4 \text { months predicted larger } \\
\text { weight and BMI at } 1,2,3(\mathrm{R}=1.46 ; 95 \% \mathrm{Cl} \\
=1.20-1.78) \text { and } 5 \text { years }(\mathrm{OR}=1.25 ; 95 \% \mathrm{Cl} \\
=1.00-1.55) \text { only among formula- or } \\
\text { mixed-fed children. Adjusted for gender, } \\
\text { body weight at } 4 \text { months }\end{array}$ \\
\hline $\begin{array}{l}\text { Butte and } \\
\text { cols. (22) }\end{array}$ & Houston, USA & $\begin{array}{l}\quad n=879 \\
\text { Hispanic } 4 \text { to } 19 \\
\text { years children } \\
\text { Viva La Familia } \\
\quad \text { Study }\end{array}$ & 1 year & $\begin{array}{l}\text { Food intake (assessed } \\
\text { through two } \\
\text { multiple-pass dietary } \\
\text { 24-hours recalls) }\end{array}$ & 1-year weight gains & $\begin{array}{l}\text { Positive correlation between weight gain and } \\
\text { energy intake normalized for fat-free mass } \\
\text { and fat mass and energy from fats }(p<0.05) \text {. } \\
\text { Negative correlation between weight gain and } \\
\text { energy from carbohydrates ( } p=0.007) \text {. } \\
\text { Adjusted for age, age squared, sex, and } \\
\text { Tanner stage, the final model to predict } \\
\text { weight gain did not retain these dietary } \\
\text { variables as independent predictors }\end{array}$ \\
\hline
\end{tabular}

TC: triceps skinfolds; SS: subscapular skinfolds; 95\%Cl: 95\% confidence interval; AC: abdominal circumference; AO: abdominal obesity; OW: overweight; OB: obesity.

* Magarey and cols. (27): at 2 years: $n=153$ ( $57.5 \%$ male); at 4 years: $n=155$ (56.8\% male); at 6 years: $n=152$ (57.9\% male); at 8 years: $n=143$ ( $54.5 \%$ male); at 11 years: $n=243$ (53.5\% male); at 13 years: $n=237$ ( $51.1 \%$ male); at 15 years: $n=218(52.3 \%$ male $)$.

\section{Infant feeding practices}

During one year after birth, Baker and cols. (7) followed 3,768 boys and girls belonging to the Denmark National Birth Cohort. They observed infant weight gain over this period according to duration of any kind of breastfeeding and to introduction of complementary food (mush or porridge). Analyses were controlled for some confounding variables, including primiparity, gestational weight gain, duration of gestation, smoking during pregnancy, infant sex, infant birth weight, infant length at one year, and infant age at time of one-year anthropometric measurements. Weight gain from birth to one year was positively associated with decreasing duration of any breastfeeding and earlier introduction of complementary food, especially within the lowest quartile of any breastfeeding $(\mathrm{p}<0.0001)$. Nonetheless, in longer duration of any breastfeeding, timing of complementary food introduction was not associated with weight gain.

Conditional weight gain from birth to three years (defined as the standardized residuals from the linear regression of three-year weight $\mathrm{Z}$-score on birth weight Z-score, with age and sex as covariates) was calculated according to the British 1990 growth references for 10,533 subjects in a study performed in the United Kingdom (8). After adjustment for confounders, among 
infants given no breast milk, conditional weight gain was significantly higher (regression coefficient $=0.06$; $95 \%$ confidence interval, $95 \% \mathrm{CI}=0.02-0.09)$, and a negative association was detected between conditional weight gain and breastfeeding duration (regression coefficient $=0.05 ; 95 \% \mathrm{CI}=0.01-0.09)$.

Using data from a smaller study sample $(\mathrm{n}=596)$, but over a slightly longer period of follow-up, Santos and cols. (9) tracked weight and length or height, as well as related anthropometric indices (weight for age, length/height for age, weight for length/height $\mathrm{z}$ scores) at one and four years in the Pelotas Birth Cohort children. The exposure of interest was the addition of corn or rice flour to cow's milk, i.e. the use of a milk thickener, between three and six months of life. Adjustment for confounders was performed. The use of milk thickener was identified in $44.6 \%$ of children during the third and sixth months of life. Positive association between use of milk thickener and weight $(\beta$ $=0.160 ; 95 \% \mathrm{CI}=0.009-0.312)$, length $(\beta=0.540$; $95 \% \mathrm{CI}=0.141-0.939)$, weight for age $\mathrm{Z}$-score $(\beta=$ $0.155 ; 95 \% \mathrm{CI}=0.013-0.296)$ and length for age $\mathrm{Z}$ score $(\beta=0.188 ; 95 \% \mathrm{CI}=0.051-0.325)$ was found in the adjusted analysis at one year, but no significant associations were present between the exposure variable and anthropometric indices at four years.

The prevalence of overweight and weight for height $\mathrm{Z}$-score of 1,273 boys and girls from this same Brazilian birth cohort study were measured four years after birth, aiming to investigate possible relationships with total and predominant breastfeeding duration (10). Overweight was defined as weight for height Z-score $>2$ using the NCHS/WHO reference curve. Authors conducted analysis adjusting for potential confounders (infant sex, skin color and birth weight, assets index, maternal schooling, smoking during pregnancy, prepregnancy BMI and weight gain during pregnancy) and found no linear trends and no significant associations between duration of total and predominant breastfeeding and outcomes $(\mathrm{p}>0.05)$. Among subjects who had been "ever breastfed", the odds ratio (OR) for overweight at four years was 1.83 (95\%CI $=0.53-6.28)$, and the coefficient for mean weight for height $\mathrm{Z}$-score was $0.24(95 \% \mathrm{CI}=-0.09-0.57)$.

Some protective effect of breastfeeding has been indicated in study subjects with more specific characteristics, as shown in two studies conducted in American settings. Bogen, Hanusa and Whitaker analyzed 73,458 white and black low-income children for 4 years in a ret- rospective cohort, considering breastfeeding duration with and without concurrent use of formula (11). The outcome of interest was prevalence of obesity at four years, defined as BMI at or above the $95^{\text {th }}$ percentile for age, based on the NCHS/CDC 2000 growth charts. Adjusting for various potential confounders - maternal age, education, parity, marital status, pregnancy conditions, delivery method, child gender, birth weight, birth year, and birth order -, breastfeeding showed a protective effect against obesity at four years for white children whose mothers had not smoked during pregnancy: $\mathrm{OR}=0.7 \mathrm{l}(95 \% \mathrm{CI}=0.56-0.92)$ for breastfeeding for 16 to 26 weeks without formula; $\mathrm{OR}=0.70$ $(95 \% \mathrm{CI}=0.61-0.81)$ for breastfeeding for more than 26 weeks with formula; and $\mathrm{OR}=0.55(95 \% \mathrm{CI}=0.42$ 0.71 ) for breastfeeding for more than 26 weeks without early formula introduction. Moreover, based on 177,304 low-income children evaluated in the Grummer-Strawn and Mei's study, a dose-response, protective relationship of breastfeeding duration with the risk of overweight at four years was established among nonHispanic whites, considering the same anthropometric references and adjusting analysis for confounders (child gender, birth weight, race/ethnicity, and mother's age, education, pre-pregnancy BMI, weight gain during pregnancy, postpartum smoking). The OR (95\%CI) for obesity when breastfeeding for 6 to 12 months was $0.70(0.50-0.99)$, and $0.49(0.25-0.95)$ when breastfeeding duration was greater than 12 months (12).

Along the same lines, the ALSPAC Children in Focus Cohort also studied 1,335 non-smoking mothers' children from birth to five years to observe growth patterns in both breast- and bottle-fed individuals. Despite similar birth weight, breastfed children showed slower weight and length gain versus bottle-fed children, and weight differed significantly up to 31 months of age $(\mathrm{p}=0.02)(13)$.

The earliest published study selected for this review followed 545 children for seven years in the Dundee Infant Feeding Study. The study analyzed the influence of breastfeeding and formula feeding, as well as the age at the introduction of formula and solid foods, on growth and body composition during childhood. Body composition was defined through skinfold thickness and electrical impedance and, again, analysis were conducted while adjusting for sex, birth weight, and child weight at first solid feed. An inverse association between age at introduction of solid foods and both weight $(\mathrm{p}<0.025)$ and percentage of body fat $(\mathrm{p}<$ $0.01)$ at seven years was found (14). 
Overweight status at seven years, defined as BMI at/or above the $95^{\text {th }}$ percentile for age, according to the NCHS/CDC 2000 growth charts, was also the variable of interest in the study by Stettler and cols. (15), with regard to breastfeeding initiation, which was assumed to be a potential confounder in the relationship with early rate of weight gain. Information on initial infant feeding method was available for 5,479 subjects, and no significant association between breastfeeding initiation and overweight at seven years was noted $(\mathrm{OR}=1.28$; $95 \% \mathrm{CI}=0.87-1.88$ ), while no interaction was detected for breastfeeding initiation, in the association of early rate of weight gain and overweight at seven years.

Another prospective study from birth to 9.5 years investigated childhood eating behaviors (such as picky or rapid eating, tantrums over food and nonnutritive food uses) and infant feeding behaviors (such as sucking behavior and number of feeds per day) in a group of 150 American children, as possible risk factors of childhood overweight development (BMI at/or above the $85^{\text {th }}$ percentile for age), within certain time frames (birth, infancy and childhood). Agras and cols. concluded that from among these behavioral factors, as well as an assessment of 24 hours child caloric intake, the development of childhood overweight was primarily linked to tantrums over food observed between two and five years which, in turn, correlated significantly with anger/frustration and soothability (16).

In 1999, exclusive breastfeeding duration was retrospectively investigated among 781 Swedish subjects followed between 15-16 and 17-18 years, in order to determine possible association with high BMI in adolescence $\left(\geq 85^{\text {th }}\right.$ percentile for age and sex $)$. In addition, 194 individuals had data regarding body composition measured by dual energy X-ray. After 18 years, exclusive breastfeeding for less than two months was correlated to high BMI values ( $\chi^{2}$ test; $\mathrm{p}=0.038$ ), whereas no significant associations were observed in relation to body composition. It should be outlined, nonetheless, that no adjustment for potential confounders was made (17). In a more recent study using a period of 18 years of follow-up, however, Victora and cols. (18) observed no protective effect of total or predominant breastfeeding on mean BMI, overweight status and lean or fat mass, measured by electrical impedance, in 2,250 Brazilian male adolescents from a population based sample. In this study, using the NCHS/WHO reference curve, overweight was defined as $\mathrm{BMI} \geq 85^{\text {th }}$ percentile for age and sex, and obesity as $\mathrm{BMI} \geq 85^{\text {th }}$ percentile for age and sex plus subscapular and triceps skinfolds $\geq$ $90^{\text {th }}$ percentile. They found only an inverse association between obesity status and total breastfeeding of over 12 months $(\mathrm{OR}=0.41 ; \mathrm{p}=0.006$, likelihood ratio test $)$ and predominant breastfeeding $(\mathrm{p}=0.03$ for linear trend). Adjustment for confounders (family income, maternal education, maternal BMI, skin color, maternal smoking during pregnancy, gestational age, birth weight and current behavioral variables - smoking, alcohol drinking, type of diet and physical activity) was performed, and the authors concluded that no strong result regarding the protective role of breastfeeding against adolescence obesity could be drawn, in view of the fact that associations with other adiposity variables studied were not confirmed.

A study comprising 35,526 women from the Nurses' Mothers' Cohort Study explored maternal reports of infant feeding practices, familial, maternal and birth variables of subjects allied to the Nurses' Health Study II (1989-2001). Authors evaluated the impact of breastfeeding initiation and duration on overweight and obesity at 18 years and also in late adulthood (mean age of breastfed nurses $=40.5$ years; non breastfed nurses = 39.3 years). No significant association between exposure variables and overweight (BMI between 25 and $\left.30 \mathrm{~kg} / \mathrm{m}^{2}\right)$ and obesity $\left(\mathrm{BMI} \geq 30 \mathrm{~kg} / \mathrm{m}^{2}\right)$ at 18 years or in late adulthood was found, even after adjustment for many confounding variables (age of nurse, year of birth of the nurse, maternal pre-pregnancy weight and weight gain during pregnancy, birth weight and gestational age of the nurse, mother's and father's education and occupation, home ownership of parents at time of nurse child's birth, age of nurse at menarche, parity of nurse, nurse's age at first birth, nurse's physical activity, daily energy intake) (19).

Nelson and cols. (20) evaluated 11,998 American adolescents in the nationally representative National Longitudinal Study of Adolescent Health. Data on infant feeding practices were retrospectively assessed while 850 full-sibling, non twin pairs were also assessed to account for unmeasured genetic and environmental factors. Adjusting for ethnicity and family income, an inverse association was established between the duration of any breastfeeding and overweight $(\mathrm{BMI} \geq$ $95^{\text {th }}$ percentile for age, according to the NCHS/CDC 2000 growth charts) among girls in the full cohort (for breastfeeding duration over nine months: $\mathrm{OR}=0.78$; $95 \% \mathrm{CI}=0.64-0.96)$. Nevertheless, no significant associations were found in sibling pairs' analyses, after 
adjustment for the suitable confounders (age, sex, birth order, and low birth weight status), suggesting that the effect of breastfeeding on overweight may be weak or even absent.

Complementarily, the study with the longest follow-up period observed in this review, spanning 62 years, found a negative association between breastfeeding duration and BMI at one year $(\mathrm{p}<0.05$ for linear trend), which disappeared at seven years. Besides, in 1,823 breastfed individuals belonging to sibling pairs of the Helsinki Birth Cohort, results with adjustment for confounders (sex, year of birth, size of sibship) showed a possible U-shaped association between breastfeeding duration and BMI ( $\mathrm{p}=0.08$ for quadratic trend) and percentage of body fat measured by electrical impedance $(\mathrm{p}=0.03$ for quadratic trend) in later life (2l).

\section{Food, energy and nutrient intake}

Regarding a potential relationship between metabolic and behavioral predictors of one-year weight gain, the Viva La Familia Study investigated 879 Hispanic 4-19year-old children. Two multiple-pass dietary 24-hour recalls were applied to measure food intake. Authors observed positive correlation between weight gain and energy intake normalized for fat-free mass and fat mass and energy from fats $(\mathrm{p}<0.05)$. Energy from carbohydrates was negatively correlated to weight gain $(\mathrm{p}$ $=0.007)$. After adjusting for age, age squared, sex, and Tanner stage, however, the final model to predict weight gain did not retain these dietary variables as independent predictors (22).

Also in the United States, the nationally representative Early Childhood Longitudinal Study-Kindergarten Cohort aimed to verify child overweight status at six years and, again, two years later in regard to household food insecurity at six years (23). Overweight was defined as $\mathrm{BMI} \geq 95^{\text {th }}$ percentile for age and sex, according to the NCHS/CDC 2000 growth charts, and households were classified as food secure or food insecure (with or without hunger) on the basis of answers to the US Department of Agriculture Household Food Security Scale, according to scarcity of food, for example. Out of 16,889 subjects participating in the cohort, 12,890 boys and girls had weight gain data available. Gender, age, race/ethnicity, birth weight, maternal schooling, poverty index ratio, country region, urbanization, physical activity, and family meal patterns were treated as potential confounders in the analysis. Food insecurity had a protective relationship with overweight at six years $(\mathrm{OR}=0.80 ; 0.66-0.98)$, and, considering child overweight status two years later, food insecurity was also inversely associated with overweight $(\mathrm{OR}=$ $0.73 ; 95 \% \mathrm{CI}=0.57-0.93)$.

Ong and cols. (24) investigated the weight gain of 881 British children for five years, since their birth. These children were breastfed and formula- or mixedfed and completed a one-day unweighted dietary record at four months, through which total dietary energy intake was calculated. Gender and body weight at four months constituted confounding variables, and there was a positive association between energy intake at four months and rates of rapid weight gain from zero to two years $(\mathrm{p}<0.0001$ for trend). Higher energy intake at four months predicted higher weight and BMI at one, two, three $(\mathrm{OR}=1.46 ; 95 \% \mathrm{CI}=1.20-1.78)$ and five years $(\mathrm{OR}=1.25 ; 95 \% \mathrm{CI}=1.00-1.55)$ only among children who had been formula- or mixed-fed.

In a similar period of follow-up, the Longitudinal Nepean Study assessed nutrient intake at seven to eight years using a three-day food record. The outcome of interest was total adiposity (BMI) and central adiposity (waist circumference) at 12 to 13 years. Given that no adjustment for potential confounders was performed, authors were not able to confirm significant associations between overweight and obesity at 12 to 13 years (according to the IOTF BMI criteria or waist circumference) and macronutrient intake at seven to eight years (25).

A total of 105 children were accompanied for ten years, at Denmark, under the Copenhagen Cohort Study on Infant Nutrition and Growth. When subjects attained nine months of age, their parents completed a five-day weighted food record, which included three weekdays and a weekend, in order to assess protein intake during infancy. In terms of body size and composition (dual-energy X-ray absorptiometry scanning) at ten years, no significant association between fatness in late childhood and protein intake at nine months was found. However, data suggested that a high protein intake may stimulate growth, considering that energy from protein was a predictor of weight $(\beta=0.44 ; 95 \% \mathrm{CI}=0.12$ $0.76)$ and height $(\beta=0.51 ; 95 \% \mathrm{CI}=0.13-0.90)$ at ten years, after adjustment for gender (26).

Magarey and cols. (27) investigated the energy and the energy-adjusted macronutrient intake of a minimum of 143 and a maximum of 243 Australian individuals aged between 2 and 15 years. Dietary exposure was measured by 3-4 day weighted dietary records, which 
were analyzed in order to observe alterations in body fatness at 2, 4, 6, 8, 11, 13 and 15 years (BMI, triceps and subscapular skinfolds). Adjustment for confounders (gender parental adiposity, total energy intake, level of fatness at the beginning of age interval) was carried out, and authors found a positive association between fat intake and subscapular skinfolds $(\beta=0.008$; $\mathrm{p}=0.003)$ and a negative association $(\beta=-0.003$; $\mathrm{p}=0.006$ ) between carbohydrate intake and subscapular skinfolds across 2 to 15 years, according to generalized estimating equations. However, on multiple regression analyses, macronutrient intake was again shown to be a poor predictor of adiposity at successive ages.

Finally, the study of Laitinen and cols. (28) sought some association between abdominal obesity and dietary parameters at 14 and 31 years, among 5,771 men and women, attending the Northern Finland 1966 Birth Cohort Study. Dietary variables analyzed included alcohol consumption at 14 and 31 years, and a healthy or unhealthy diet pattern (based on frequency of intake of foods rich in fiber and consumption of sausages) at 31 years. Several confounding variables were considered, such as maternal age and BMI before pregnancy, and parity and use of hormonal contraception at 31 years among women. Considering BMI at 31 years in a regression model, a positive association between abdominal obesity in men and high alcohol consumption at 31 years (comparing the highest with the lowest quartile of alcohol intake, $\mathrm{OR}=1.82 ; 95 \% \mathrm{CI}=1.17$ $2.85)$ and unhealthy $\operatorname{diet}(\mathrm{OR}=1.53 ; 95 \% \mathrm{CI}=1.03$ 2.27, compared to healthy diet) was detected. Among women, alcohol consumption at 31 years also showed a dose-response, protective relationship with abdominal obesity (when comparing the highest with the lowest quartile of alcohol intake, $\mathrm{OR}=0.54 ; 95 \% \mathrm{CI}=0.34$ $0.85)$. Female abdominal obesity was positively associated with regular alcohol consumption at 14 years (OR $=2.63 ; 95 \% \mathrm{CI}=1.44-4.80$, compared to no alcohol intake at 14 years), but disappeared when BMI at 31 years was included in the model.

\section{STRENGTHS AND LIMITATIONS OF REVIEWED STUDIES}

Associations between infancy feeding practices and the development of overweight and obesity are thought to explain some features of the association of infancy weight gain with later nutritional status. In this sense, one of the most studied aspects is breastfeeding, which promotes slow weight gain in children, protecting against overweight development. Conversely, individuals who are formula-fed or have an earlier introduction of complementary food are set to experience more rapid weight gain in early infancy and an increased risk of obesity in childhood and adolescence, given the possibility of overfeeding - which would be unlikely to happen with breastfed children, who have to stimulate breast milk production by suckling.

Our review of these 22 longitudinal investigations has revealed some inconsistency across results regarding associations among infant feeding practices, patterns of childhood growth and the nutritional status exhibited in later life. Studies with shorter periods of follow-up, generally between birth and one to three years of life, seemed to indicate some protective effect of breastfeeding in the prevention of overweight and obesity, observing decreasing weight gain with longer durations of breastfeeding. In longer follow-up periods, however, the majority of associations between nutritional status in childhood, adolescence or adulthood and breastfeeding initiation and duration, as well as the use of milk thickeners and introduction of complementary food, were actually weakened or completely disappeared. In the study with the longest period of followup examined in this review, an interesting U-shaped association between breastfeeding duration and BMI and fat mass at 60 years of life was established, suggesting that breastfeeding for periods which are either too short or too long could be detrimental to growth and development. Food insecurity was negatively associated with overweight in childhood, and some articles provided evidence linking higher energy intake in infancy to higher weight and BMI during childhood, especially among non-breastfed children, as well as higher energy from protein in infancy to higher weight and height at ten years. In several other studies, however, energy and macronutrient intake were not prospectively linked to body composition, overweight or obesity. Other dietary variables measured in infancy and childhood were also not included in regression models to predict weight gain and adiposity in later life.

Possible reasons for these inconsistencies may include variations in study setting and design, number of subjects, statistical power, use of different dietary assessment methods, definitions of infant feeding practices, dietary variables and overweight or obesity status, age at outcome assessment, and extent of adjustment for potentially confounding factors. 
In this review, the main controlled confounding variables were sex, skin color, family income, birth weight and several maternal characteristics (age, BMI, education level, smoking during pregnancy etc). Evidently, more recent studies were able to overcome confounding variables in a more effectively by using refined statistical techniques. In spite of this, it should be emphasized that the measurement of confounding factors may often be poor and underestimated, because of the difficulties in selecting and analyzing proper proxy variables. Some studies therefore advise new design approaches, such as comparisons with sibling pairs, which can manage unmeasured environmental and genetic characteristics $(20,21)$, and conceptual frameworks that allow the organization of risk factors into a model with diverse hierarchical levels of determination (distal and proximal determinants) related to the outcome of interest, to properly identify causal mechanisms $(29,30)$.

In addition, it is noteworthy that out of the longitudinal study results illustrated in the articles included in this review, only the Pelotas Birth Cohort presented evidence from a developing country. There are certainly distinct behaviors influencing dietary practices together with contrasting socioeconomic status, between developing and developed countries, and even among different regions within the same country (31). Consequently, different variables exert influence and can act as confounding factors in the relationship between infant feeding practices, patterns of childhood growth and the nutritional status exhibited in adult life. In Brazil's case, the city of Pelotas, located in the Southern region, represents a wealthier area inhabited by a majority of white subjects, and thus is not representative of other regions of the country.

Along with these limitations, some studies evaluated in this review were not population-based or involved a small representative sample as depicted in tables 1 and 2. Other investigations were characterized by brief periods of follow-up, thereby preventing further conclusions on the nutritional status in later phases of life. Moreover, it is noteworthy that accurate dietary assessment often represents a challenge for researchers. There is, indeed, a higher frequency of longitudinal studies detailing growth and development parameters spanning longer periods from birth to late adulthood which employ anthropometric variables only, than there are longitudinal studies using dietary variables to evaluate this relationship. In some studies presented, infant feeding practices had to be assessed retrospectively through health records or mothers' reports, where this is considered a reliable approach for this purpose (32). When delving into food, energy and nutrient intake, assessment methods were satisfactorily exploited, but undoubtedly relied on self-report and always have inherent advantages and shortcomings that ultimately dictate their adoption under the situation at hand (33).

Therefore, in a bid to contribute further consistent evidence to the current literature, future studies are clearly needed in the field of infant feeding practices and dietary variables associated to childhood growth and nutritional status in adulthood. Such studies should have adequate designs to determine causal relationships, made feasible by means of longitudinal investigations that preferentially appraise population-based samples for periods of follow-up that cover the key phases of human growth. Lastly, given the current lack of studies in developing countries, future studies should focus on developing countries, and provide adequate measurement and treatment of potential confounding factors.

\section{CONCLUSIONS}

In conclusion, this non-systematic review showed that longitudinal studies yield some inconsistent associations among infant feeding practices, childhood growth and obesity in adult life. Over short follow-up periods, breastfeeding may play a role in preventing overweight development, while energy and protein intake during infancy might be associated with weight and height attained in later years. Nevertheless, these associations seem to be weakened or even eliminated when longer periods of monitoring are considered. Further research particularly in developing countries, would be valuable to contribute more solid findings to the current literature.

Acknowledgements: BHL is supported by PhD scholarship from Fundação de Amparo à Pesquisa do Estado de São Paulo (Fapesp) protocol 08/57796-3. MAC is supported by research grant from National Counsel of Technological and Scientific Development (CNPq), protocol 300167/97-0.

Disclosure: no potential conflict of interest relevant to this article was reported.

\section{REFERENCES}

1. Victora CG, Adair L, Fall C, Hallal PC, Martorell R, Ritcher L, et al. Maternal and child undernutrition: consequences for adult health and human capital. Lancet. 2008;371(9609):340-57.

2. Hoffman DJ, Roberts SB, Verreschi I, Martins PA, de Nascimento $\mathrm{C}$, Tucker $\mathrm{KL}$, et al. Regulation of energy intake may be impaired in 
nutritionally stunted children from the shantytowns of São Paulo, Brazil. J Nutr. 2000;130(9):2265-70.

3. Hoffman DJ, Sawaya AL, Verreschi I, Tucker KL, Roberts SB. Why are nutritionally stunted children at increased risk of obesity? Studies of metabolic rate and fat oxidation in shantytown children from São Paulo, Brazil. Am J Clin Nutr. 2000;72(3):702-7.

4. Fernald LC, Neufeld LM. Overweight with concurrent stunting in very young children from rural Mexico: prevalence and associated factors. Eur J Clin Nutr. 2007;61(5):623-32.

5. Jingxiong J, Rosenqvist U, Huishan W, Koletzko B, Guangli L, Jing $\mathrm{H}$, et al. Relationship of parental characteristics and feeding practices to overweight in infants and young children in Beijing, China. Public Health Nutr. 2009;12(7):973-8.

6. ColeTJ, Bellizzi MC, Flegal KM, Dietz WH. Establishing a standard definition for child overweight and obesity worldwide: international survey. BMJ. 2000;320(7244):1240-43.

7. Baker JL, Michaelsen KF, Rasmussen KM, Sørensen TI. Maternal prepregnant body mass index, duration of breastfeeding, and timing of complementary food introduction are associated with infant weight gain. Am J Clin Nutr. 2004;80(6):1579-88.

8. Griffiths LJ, Smeeth L, Hawkins SS, ColeTJ, Dezteaux C. Effects of infant feeding practice on weight gain from birth to 3 years. Arch Dis Child. 2008 [epub ahead of print].

9. Santos IS, Matijasevich A, Valle NCJ, Gigante DP, Moura DR. Milk thickeners do not influence anthropometric indices in childhood. Food Nutr Bull. 2006;27(3):245-51.

10. Araújo CL, Victora CG, Hallal PC, Gigante DP. Breastfeeding and overweight in childhood: evidence from the Pelotas 1993 birth cohort study. Int J Obes. 2006;30(3):500-6.

11. Bogen DL, Hanusa BH, Whitaker WC. The effect of breast-feeding with and without formula use on the risk of obesity at 4 years of age. Obes Res. 2004;12(9):1527-35.

12. Grummer-Strawn LM, Mei Z; Centers for Disease Control and Prevention Pediatric Nutrition Surveillance System. Does breastfeeding protect against pediatric overweight? Analysis of longitudinal data from the Centers of Disease Control and Prevention Pediatric Nutrition Surveillance System. Pediatrics. 2004;113(2):e81-6.

13. Ong KKL, Preece MA, Emmett PM, Ahmed ML, Dunger DB; ALSPAC Study Team. Size at birth and early childhood growth in relation to maternal smoking, parity and infant breast-feeding: longitudinal birth cohort study and analysis. Pediatr Res. 2002;52(6):863-7.

14. Wilson AC, Forsyth JS, Greene SA, Irvine L, Hau C, Howie PW. Relation of infant diet to childhood health: seven year follow up of cohort of children in Dundee infant feeding study. BMJ. 1998;316(7124):21-5.

15. Stettler N, Zemel BS, Kumanyika S, Stallings VA. Infant weight gain and childhood overweight status in a multicenter, cohort study. Pediatrics. 2002;109(2):194-9.

16. Agras WS, Hammer LD, McNicholas F, Kraemer HC. Risk factors for childhood overweight: a prospective study from birth to 9.5 years. J Pediatr. 2004;145(1):20-5.

17. Tulldahl J, Pettersson K, Andersson SW, Hulthén L. Mode of infant feeding and achieved growth in adolescence: early feeding patterns in relation to growth and body composition in adolescence. Obes Res. 1999;7(5):431-7.

18. Victora CG, Barros F, Lima RC, Horta BL, Wells J. Anthropometry and body composition of 18 year old med according to duration of breast feeding: birth cohort study from Brazil. BMJ. 2003;327(7420):901-5.

19. Michels KB, Willett WC, Graubard BI, Vaidya RL, Cantwell $M M$, Sansburry LB, et al. A longitudinal study of infant feeding and obesity throughout life course. Int $\mathrm{J}$ Obes (Lond). 2007;31(7):1078-85.

20. Nelson MC, Gordon-Larsen P, Adair LS. Are adolescents who were breast-fed less likely to be overweight? Analyses of sibling pairs to reduce confounding. Epidemiology. 2005;16(2):247-53.

21. O'Tierney P, Barker DJP, Osmond C, Kajantie E, Eriksson JG. Duration of breast-feeding and adiposity in adult life. J Nutr. 2009;139(2):422S-5S.

22. Butte NF, Cai G, Cole SA, Wilson TA, Fisher JO, Zakeri IF, et al. Metabolic and behavioral predictors of weight gain in Hispanic children: the Viva La Familia Study. Am J Clin Nutr. 2007;85(6):1478-85.

23. Rose D, Bodor JN. Household food insecurity and overweight status in young school children: results from the Early Childhood Longitudinal Study. Pediatrics. 2006;117(2):464-73.

24. Ong KK, Emmett PM, Noble S, Ness A, Dunger DB; ALSPAC Study Team. Dietary energy intake at the age of 4 months predicts postnatal weight gain and childhood body mass index. Pediatrics. 2006;117(3):e503-8.

25. Garnett SP, Cowell CT, Baur LA, Shrewsbury VA, Chan A, Crawford $D$, et al. Increasing central adiposity: the Nepean longitudinal study of young people aged 7-8 to $12-13 y$. Int J Obes. 2005;29(11):1353-60.

26. Hoppe C, Molgraard C, Thomsen BL, Juul A, Michaelsen KL. Protein intake at 9 mo of age is associated with body size but not with body fat in 10-y-old Danish children. Am J Clin Nutr. 2004;79(3):494-501.

27. Magarey AM, Daniels LA, Boulton TJC, Cockington RA. Does fat intake predict adiposity in healthy children and adolescents aged 2-15y? A longitudinal analysis. Eur J Clin Nutr. 2001;55(6):471-81.

28. Laitinen J, Pietiläinen $\mathrm{K}$, Wadsworth $\mathrm{M}$, Sovio $U$, Järvelin MR. Predictors of abdominal obesity among 31-y-old men and women born in Northern Finland in 1966. Eur J Clin Nutr. 2004;58(1):180-90.

29. Victora CG, Huttly SR, Fuchs SC, Olinto MTA. The role of conceptual frameworks in epidemiological analysis: a hierarchical approach. Int J Epidemiol. 1997;26(1):224-7.

30. Olinto MTA. Reflexões sobre o uso do conceito de gênero e/ou sexo na epidemiologia: um exemplo nos modelos hierarquizados de análise. Rev Bras Epidemiol. 1998;1:161-9.

31. Victora CG, Barros FC. Cohort profile:The 1982 Pelotas (Brazil) Birth Cohort Study. Int J Epidemiol. 2006;35(2):237-42.

32. Troy LM, Michels KB, Hunter DJ, Spiegelman D, Manson JE, Colditz GA, et al. Self-reported birthweight and history of having been breastfed among younger women: an assessment of validity. Int J Epidemiol. 1996;25(1):122-7.

33. Thompson FE, Byers T. Dietary assessment resource manual. J Nutr. 1994;124(11 Suppl):2245S-2317S. 